\title{
The Chittagong Hill Tracts Peace Accord: A Landmark Model for a Viable Solution to the Refugee Problem
}

\author{
K. C. Saha
}

\begin{abstract}
The Chittagong Hill Tracts (CHT) area of Bangladesh, home to the Chakma and eleven other major tribes, has experienced civil strife since the early 1970 s. The demand for autonomy by the local tribal leaders and the settlement of Bengalees into the CHT sparked armed insurgency. The fighting between the tribal hill people and Bangladesh army continued for almost two decades, resulting in a large flight of predominantly Chakma refugees into India. Talks between India and Bangladesh officials regarding these refugees resulted in the creation of tribally-led local governments in the $\mathrm{CHT}$, and a rehabilitation package for Chakma and other refugees. This process laid the groundworkfor the Chittagong Hill Tracts Peace Accord signed on December 2, 1997 between the Bangladesh government and the Hill Tracts People's Solidarity Association (PCJSS). Shortly after, about 60,000 refugees returned to the CHT from India, and guerillas surrendered their arms. The objective of this background paper is to examine the Chittagong Hill Tracts Peace Accord and its role in providing a framework for a viable solution to the refugee problem in the $\mathrm{CHT}$. It also highlights those aspects of the Accord which serve as a model for preventing refugee flight and displacement of people in any conflict situation.
\end{abstract}

\section{Précis}

La zone des Traités de la Colline de Chittagong (Chittagong Hill Tracts: CHT)

K. C. Saha is Joint Secretary, Department of Supply, Government of India. Views expressed in this article are the author's and should in no way be construed as the view of the Government of India.

The author is thankful to Prof. B. S. Chimni, School of International Studies, Jawaharlal Nehru University, New Delhi, for his guidance and valuable suggestions. au Bangladesh, patrie des Chakma et de onze autres importantes tribus, faitl'objet d'enjeux sécessionnistes depuis le début des années 1970. Les aspirations autonomistes des chef tribaux locaux et l'installation de bengalis sur la CHT a fait éclater l'insurrection armée. Les affrontements entre les populations tribales de la colline et l'armée du Bangladesh se sont poursuivis pendant presque deux décennies, entraînant un flot massif de réfugiés à prédominance Chakma vers l'Inde. Des pourparlersentrel'Indeet les officiels du Bangladesh au sujet de ces réfugiés ont menéà la création de gouvernements locaux sous contrôle tribal dans la CHT, ainsi qu'à une entente de réhabilitation pour les Chakma et autres réfugiés. Ce processus a pavé la voie à l'Accords de Paix de la zone des Traités de la Colline de Chittagong, signé le 2 décembre 1997 entrelegouvernement du Bangladesh et l'Association de Solidarité des Peuples de la Colline (PCJSS). Peu après, environ 60,000 réfugiés sont retournés dans la CHT depuis l'Inde, et la guérilla a déposé les armes. Le but de cet article de fond est de procéder à un examen de l'Accord de Paix de la zone des Traités de la Colline de Chittagong, et le rôle qu'il joue dans la mise en place d'un cadre susceptible de menerà une solution viable du problème des réfugiés dans la CHT. L'articleattire aussil'attention sur les aspects de l'accord pouvant servir de modele pour une prévention des flots de réfugiés dans toutes situations de conflit.

\section{Historical Background}

On December 2, 1997, a landmark peace accord aimed at ending the decades-old insurgency in the Chittagong Hill Tracts (CHT) in Bangladesh was signed by the Government of Bangladesh and the Hill Tracts Peoples' Solidarity Association (PCJSS-or Parbottiya Chattogram Jana Shanghati Samiti). The accord was widely acclaimed by the international community as a major peace initiative.

The CHT, comprising of the three districts-Khagrachhari, Bandarban and Rangamati-lies in the southeasternmost part of Bangladesh, wedged between the Indian States of Tripura and Mizoram. The CHThas an area of 5,093 sq. miles, which represents 10 percent of the total land area of Bangladesh and contains 47 percent of its forestland. The major tribes of the area are Chakma, Marma, Tripura, Tanchangya, Reang, Chak, Khyang, Khumi, Murrung, Lushai, Bawm, and Pankho. The largest tribes in the CHT are the Chakmas and the Marmas, who account for ninetenths of the tribal population. The Chakmas and the Marmas are Buddhists. The British, under the CHT Regulation 1900, exempted the CHT from their administration as an "Excluded Area" and left the tribal people to rule themselves ostensibly to preserve minority "tribal" culture and heritage.

Demographic changes were enforced by the Pakistan Government and later by the Government of Bangladesh, whereby people from the plain areas called Bengalees were encouraged to settle in the CHT. This led to the growth of Chakma and other insurgencies among indigenous people. The hill people organized themselves and formed the PCJSS in 1972 to champion the cause of regional autonomy. An armed military wing of PCJSS called Shanti Bahini was created in 1975. Shanti Bahini took up arms against the Bangladesh army and the settlers. In the ensuing war, the army and the police carried out counterinsurgency activities.

The PCJSS made a number of demands: (a) self determination with a separate legislature; (b) restoration of the fundamental rights of the tribal people; (c) constitutional arrangements to ensure the preservation of the tribal national identity, and (d) a total ban on 
further settlements, dismantling of the existing ones, and transfer of land ownership to the tribal people.

The International Working Group for Indigenous Affairs submitted a report on human rights situation in the $\mathrm{CHT}$ to the Social and Economic Council of the United Nations. In the report, the working group referred to the CHT Commission report of May 1991, which had observed that

there have been massive human rights violations in the Chittagong Hill Tracts, which constitute a genocidal process. Hill people have been murdered, crippled, raped, tortured, imprisoned and deprived of their homes and livelihood. They have been denied civil and political rights. They have been denied economic, social and cultural rights. There has been extensive and massive illegality over land under Bangladesh Law. ${ }^{1}$

The CHT Commission had recommended that

No further settlement in the CHT by outside settlers should be permitted. Involuntary reorganisation of both hill people and Bengalees into cluster villages in the $\mathrm{CHT}$ should be dismantled immediately. CHT must be demilitarised. Autonomous political institutions stronger than the existing District Councils should be established. There should be a referendum in the CHT on autonomy with the voting confined to the hill people. There should be constitutional protection of any future autonomous government-a Continuing Monitoring body to continually watch human rights in CHT. A Special Rapporteur of the UN should be established, supplemented by continuing investigations by ILO and competent NGOs. ${ }^{2}$

Reacting to the Commission's report, the Bangladesh permanent representative to the United Nations in Geneva said that

there could be no question of any indigenous population and the Constitution of Bangladesh does not recognise any individual grouping within Bangladesh. The fact that the people of CHT have freely elected three members of Parliament, reconfirms the degree of political freedom and legal rights enjoyed by all people of Bangladesh including those living in $\mathrm{CHT}$. The report of the Commission is biased and flawed. The report of the Amnesty International, the 1991 report of the U.S. State Department on Human Rights, the reports of the responsible church organisations and above all the Subcommission on Human Rights expressed satisfaction over the treatment of the people of the CHT by the Government of Bangladesh. $\mathrm{CHT}$ is one of the most thinly populated areas. About 10 percent of the land area is now being inhabited by 0.5 percent of the population. Bangladesh is probably the most densely populated area of the world. Hence, movement of people in search of safe homestead and reasonable living is a normal phenomenon in our country. Our laws, like those of any free country, permit movement of people from $\mathrm{CHT}$ to other areas of Bangladesh in search of home and employment and vice versa. Armed insurgents called Shanti Bahinis are causing widespread destruction and death in the CHT area. Villagers have been encouraged to organize themselves into cluster villages so that the Government could provide proper educational and health facilities to the people of the area and create necessary social infrastructure. The armed insurgents find such a settled and prosperous life against the sinister designs of their paymasters. It is a normal practice in a civilized country to call upon the army to assist the civil authorities in emergencies. Bangladesh laws provide for assistance of Army in aid of civil authorities in emergency situation. In CHT, there is an on-going armed insurgency by a small group of adventurers who are being financed and trained and armed by anti-Bangladesh forces. The normal police force at the disposal of civil authorities of $\mathrm{CHT}$ do not have the fire power and fighting skill to effectively deal with these armed insurgents who are equipped with the latest automatic weapons and explosives. As soon as these ter rorist activities by outsiders can be brought to an end, there would be no need to maintain army presence in CHT. $^{3}$
There were aseries of attacks on tribal peoples by settlers and the armed forces. For instance, on March 25, 1980, 300 Chakmas were killed in the Kalampati massacre, In the Bagaichhari massacre of August 9, 1988, tribals were attacked in retaliation to a Shanti Bahini attack on the army troops. In another incident, the Longdu massacre of May 4, 1989, settlers attacked local Chakma villagers. The Shanti Bahini, on the other hand, launched attacks on non-tribal villagers and the armed forces.

The war and instability in the CHT led to refugee migrations to the State of Tripura in India since 1986. In February 1987 , for example, there were 49,000 , mostly Chakma refugees living in camps in Tripura. ${ }^{4}$ By 1997, the number had gone up to $60,000.5$ The Chakma refugee issue became a major irritant in Indo-Bangladesh relations. There was a difference of opinion between India and Bangladesh on the number of refugees. According to the authorities in Bangladesh, the numbers of refugees, as provided by the Government of India, were highly inflated. It was also alleged that theIndian Government was backing the Shanti Bahini insurgents who operated from across the border in India. Furthermore, the Government of Bangladesh maintained that the Indian authorities in Tripuraprevented the repatriation of Chakma and other refugees. The Indian Government, however, denied these charges and maintained that the Bangladesh Government had not taken any significant steps to address the root causes of nefugee migration. The Bangladesh Government, on the other hand, maintained that the flow of Chakma and other refugees was due to the terror created by Shanti Bahini. For instance, in a press conference on May 13, 1987, the Bangladedh Foreign Minister said that

Shanti Bahini are indulging in antistate activities which no government would tolerate. They are inspired by an alien political ideology [that] seems to have been rejected by the vast majority of tribes themselves. ${ }^{6}$

As a confidence-building measure, the Bangladesh Foreign Minister indicated on April 7, 1988, that 
everything possible has been done and is being done by the government, not only for the early return of refugees to their hearths and homes but also to ensure that the tribal people in the CHT live in peace with their ethnic, religious and cultural identity not only protected but also promoted in every possible way. ${ }^{7}$

A bill was passed in the Bangladesh Parliament to allow for the creation of local governments in all the three districts of the CHT: The governments were to beled by those elected by all members of the Local Government Council. However, the Local Government Councils established in the districts did not meet the aspirations of PCJSS, because the latter always demanded that $a$ Regional Council be formed with a clause in the Constitution guaranteeing the status of the Regional Council.

Several rounds of talks were held between India and Bangladesh regarding the problem of insurgency in the $\mathrm{CHT}$ and the repatriation of Chakma and other refugees. During a visit by the Prime Minister of Banglade $\$$ h to India in 1992, the two leaders discussed the issue:

The two Prime Ministers agreed to arrange speedy repatriation of all Chakma refugees to Bangladesh in full safety and security. In this context, the Bangladesh side agreed to set up a representative political level committee that would encourage the refugees to return. The Indian side assured that its authorities would cooperate fully in the proces $\$$ of repatriation. ${ }^{8}$

The Bangladesh Government sent delegations of tribal leaders, senior officers of the government, and ministers to visit refugee camps in Tripura and convince the refugees to return. The Government of Bangladesh also announced a revised rehabilitation package for repatriated refugees in the $\mathrm{CHT}$. The package included: financial assistance to each family for construction of dwelling units and development of agricultural land; allotment of land for settlement; general amnesty for insurgents; restoration of land to returnees; adequate arrangement for security of life and property of the returnees; and facilities for free admission to schools and colleges for returnee students.

Although an agreement was signed by the two countries to facilitate repatriation, implementation of the agreement was problematic.. This was partly so, because the refugees remained unconvinced about assurances given by the Government of Bangladesh about safety and security in Bangladesh. Also, they remained sceptical about the promised rehabilitation package. Thus, despite the measures initiated by the Government of Bangladesh, refugee repatriation could not be effected.

\section{The Chittagong Hill Tracts Peace Accord}

The Accord ${ }^{9}$ was signed on behalf of the government by the Chief Whip of the Bangladesh National Parliament and the Convener of the National Committee on CHT, Abul Hasnat Abdullah. The Chairman of PCJSS, Jyotindriya Bodhipriya Larma, alias Shantu Larma, signed it on behalf of PCJSS. The Preamble of the Accord states that the Accord has been signed by PCISS, keeping full and unswerved allegiance to Bangladesh's state sovereignty and territorial integrity in Bangladesh's CHT region under the jurisdiction of the Constitution of the People's Republic of Bangladesh. The main features of the Accord are:

- General amnesty to Shanti Bahini members.

- Shanti Bahini cadres to surrender arms.

- Criminal cases against them to be withdrawn, those in prison to be freed, and assistance to be provided to restart life.

- Reinstatementinjobsingovernment and autonomous bodies.

- Bank interests to be waived.

- Bank credit to be provided on easy terms.

- A Tribal Welfare Ministry to be formed in the CHT.

- Regional Council to be constituted which willoversee bottlenecks in the administration and development activities.
- Hill District Council of each district to have power to recruit local police up to the rank of Sub-Inspector.

- Tribal people to get preference for all posts in the government, semi-government and autonomous bodies in the CHT.

- No khas mahal land (Government Land) can be leased out, purchased, sold or transferred without the permission of the Hill Council.

- Hill District Council to collect the land revenue.

- Hill District Council to have power over land and land administration, local police, tribal law and social justice, youth welfare, environmental protection and development, local tourism, licence for local trade and commerce, and regulations regarding $j$ hum or shifting cultivation.

- The appointment of a land commission to be headed by a retired judge that would settle all land disputes.

- Land commission empowered to cancel the ownership of land, which was illegally captured and allotted.

- A three-member committee to oversee the implementation of the Accord.

Though the Accord was signed on December 2, 1997 by the Government of Bangladesh, led by the Awami League, there had been several meetings and negotiations by the representatives of the previous governments and the Chakma leaders. For instance, in 1980, President Zia, after meeting with Chakma leaders, had said that

we are doing some wrong there. We are being unfair to the tribe. It is a political problem that is being dealt with by police and army action. Yet it can be settled politically very easily. We have no basis for taking over these lands and pushing these people into a corner. We should at least call a meeting of the tribal leaders and ask them about their demands. ${ }^{10}$

The peace process was initiated in 1982 after consensus was reached in the army that it would be difficult to resolve the issue of Chakma and other ethnic groups without political settlement. In July 1982, after coming to power, General Ershad met Chakma leaders and 
decided to propose a package deal that would resolve the Hill Tracts crisis. He formed a National Committee in 1987 to find a political solution to the problem. In February 1989, a bill was passed in Parliament to allow the creation of local governments in all the three districts in the CHT. In 1992, the government, led by the Bangladesh National Party (BNP), formed a committee to resolve the Chakma problem. In October 1996, the National Committee on CHT was reconstituted by the Awami League Government in order to give fresh impetus to talks between the government and PCJSS.

Since the signing of the Accord, there has been polarization in public opinion. Opposition political parties; in particular the Bangladesh National Party (BNP) and Jatiya Party (JP) have attacked the entire Accord. Their main arguments for opposing the Accord are as follows:

- The Constitution does not recognize the CHT as a "secluded" or "special area." The Constitution does not permit demarcation of an area of the country for some people.

- The unitary character of the Constitution had been violated.

- Chief Whip Abul Hasnat Abdullah had signed on behalf of the governmentbut since he was notholding an executive office he had no legal standing. Similarly, Jyotindriya Bodhipriya Larma had no authority to sign the Accord on behalf of the people of the CHT as he was not an elected representative and had no mandate to represent the people of the area.

- Provisions of the Accord violated the Constitution and undermined national sovereignty.

- The Accord could be made only between two sovereign countries but not by parties within a country.

- Shanti Bahini leaders have got what they wanted minus a province and power to legislate.

- Government did not have people's mandate to sign the Accord.

- The Accord means "self-rule" for the tribals. One-tenth of the country's territory had been surrendered.
- The Accord may harm territorial integrity and encourage a similar clamour for devolution of powers in other areas of the country.

- The Accord would encourage the misguided tribals to demand autonomy and finally independence.

- During peace negotiations, nontribals, who constitute 50 percent of the population, should have been consulted but had instead been left out of the consultations. The government acted unilaterally in extending all facilities to insurgents.

- Non-tribal settlers fear retaliation and persecution once the tribes are at the helm of power. The Accord has virtually made thenon-tribal population "second class citizens."

- Induction of insurgents into the police force would be an embarrassment for regular forces, while the non-tribals have apprehensions that the insurgents-turned-police would pursue them.

- Non-tribals may resort to insurgency activities and thus one kind of insurgency would be substituted by another.

- All the Shanti Bahini men may not surrender arms.

- The proposed Regional Council with its vast powers is, in effect, a miniature legislature. And nothing will move without the prior consent of the omnipotent Regional Council.

- The Hill District Councils and the Regional Councils should have proportional representation of all tribals and non-tribals. Reserving the office of the Chief of District Councils and Regional Council for tribals, and non-proportional representation of tribals and non-tribals in these bodies, would be discrimination and a violation of citizen's rights that the Constitution has guaranteed.

Contrary to the arguments of those whoare opposed to the Accord, the Government of the Awami League and others who are in favour of the Accord argue that:

- The Awami League Government had shown courage, commitment and willingness to take risks in solv- ing the several decades-old problem in the CHT area.

- State sovereignty and territorial integrity havenot been compromised.

- The Aiccord would ensure human rights It is basically an instrument of understanding whereby insurgents would come under legal and constitutional boundaries.

- The principle of coexistence between non-tribal and tribal people has been basically upheld through the Adcord and it cannotbe said that the government has rewarded the terrorists.

- The CHT has been enjoying special statusisince the promulgation of Hill Tracts Regulation Act 1900 during the British rule. The Hill Tracts Manual of 1900 was cancelled in 1963 and was not incorporated in the Bangladesh Constitution. The special status was again protected under the 1989 Act passed by the Ershad Government whereby District Councils were formed.

- Regional Council is like a development agency coordinating the activities of the three district councils and has no legislative power. There is no bar in the Constitution to establish such a body. Moreover, the government thas the full authority to dissolve the Regional Council and District Councils.

- Tribals and non-tribals, having a common stake in the economic growth of the area, will workin close cooperation. Once peace is restored, natural resources such as timber, agro-based products, fisheries, oil, gas, and tourism could be properly exploited which will lead to the development of the $\mathrm{CHT}$ area.

- The Accord has enhanced the country's image and paved the way for national development through peace and harmony.

In order to givelegal clout to the peace accord, the CHT Regional Council Bill and the three Local Government Councils (Amendment Bills) for the three hill districts in the CHT, were passed by the NationalParliament in May 1998. However, there had been strong opposition to the signing of the Accord and the

Refuge, Vol. 18, No. 2 (April 1999) 
passing of bills. For example, there have been bandhs, protest marches and violent agitations which were only put down by strong police action\$. To block the passage of the bills, the opposition political parties also boycotted the Parliament. A writ petition was alsofiled in the High Court challenging the legalities of the CHT Peace Accord. The Court, however, held that the petition was not maintainable. The necessary legal cover to the Accord could be given only after a gap of four months.

The immediate impact of signing the Accord was the repatriation of 60,000 refugees belonging to the Chakma and other indigenous groups. The refugee repatriation began in the first week of January 1998, and by March, 1998, all the refugees had repatriated. They repatriated in batches, and were welcomed back home by local officials, political leaders, relatives and old neighbours. Senior officials of the Indian State of Tripura saw the refugees off as they left Indian soil. It was suggested that the tribal leaders deliberately allowed refugees to repatriate in batches in order to maintain the necessary leverages for negotiation and implementation of the terms of the Accord.

The Accord also led to the surrender of arms by the Shanti Bahinil guerillas. On February 10, 1998, for example, 739 Shanti Bahini guerillas surrendered their arms and left for theirhomes. Each guerilla received a cheque of Taka 50,000 for resettlement and reintegration.

Representatives of foreign missions, and journalists witnessed the formal arms surrender. On the occasion, the U.S. ambassador to Bangladesh said that "it would begin a new chapter on human rights in Bangladesh."11 The Australian Foreign Minister said that, "the signing of the CHT Accord without any third party participation $\phi r$ involvement was indeed laudable. There had been precedents of concluding such accords with the insurgent groups." 12 The British Prime Minister said that, "I am particularly impressed with the deposit of weapons by former tribal leaders." ${ }^{\prime 13}$
In order to ensure the security of the ShantiBahinimembers, Village Defence committees have been constituted. Three thousand Village Defence Party (VDP) members who were equipped with firearms to assist the army in policing the three hill districts of the CHT during tribal insurgency have since been disarmed. About 1,000 Shanti Bahini members have been recruited to the Police Department. A massive program of refugee resettlement with assistance from other countries has been proposed. Representatives of donor countries and agencies have sought detailed information required for carrying out the resettlement and development programs in the CHT. The Australian Government has already agreed to provide financial support for development activities in the $\mathrm{CHT}$. It has been said that the Australian assistance would be provided as a "peace dividend" for the government's "excellent" initiative in ending the longdrawn conflict. The Bangladesh Government is likely to seek $\$ 100 \mathrm{mil}-$ lion from the donors for the implementation of short-term development programs in the $\mathrm{CHT}$ on an emergency basis. The government has asked the Special Affairs Division to prepare project proposals seeking financial assistance of approximately $\$ 100$ million from the donors. Emphasis has been placed on the resettlement of refugees and the construction of infrastructure such as schools, clinics, rural feeder roads, and village markets.

\section{Implications of the Accord}

The Chittagong Hill Tracts Peace Accord is an attempt to find a solution to the insurgency problem in the CHT within the framework of the Constitution. The disturbed conditions in the CHT continued for a long period because, on the one hand, the insurgents who claimed to fight for the cause of tribals carried on their activities and, on the other hand, the police and the army carried on the counter-insurgency operations. There were serious violations of the human rights of the hill people, causing a massive refugee flow to India. The Accord is expected to reverse such a trend and is supposed to guarantee the hill people that their human rights will be protected. It is a recognition of the fact that the life and property of ethnic minority groups need to be protected by special legal provisions and institutional changes in the political and administrative systems. The Accord also emphasizes that political, economic, civil, social and cultural rights would be maintained by necessary legal and administrative measures.

It will be worthwhile to consider how such an important peace accord came to be signed. There had been other peace initiatives by the Government of Bangladesh in the past, but the real transition point came during the June 1996 Parliamentary election. The Awami League declared in its election manifesto that if voted to power, it would earnestly try for a permanent solution to the CHT insurgency problem. The Awami League got an overwhelming majority in the Parliamentary elections. Immediately after coming to power, the Awami League Government initiated important measuressuch as reconstituting the National Committee on the CHT, which started dialogue with the tribal leaders, and visiting the refugee camps in theState of Tripura in India. The Government of India, being the host country, played a very important role in convincing the refugee leaders that they should co-operate with the Bangladesh authorities in finding a permanent solution to the crisis in the CHT.

The previous governments in Bangladesh had maintained a very rigid attitude towards the insurgents and had made clear that there would be no compromise with the insurgents in finding a solution to the CHT crisis. The approach they followed was to intensify police and army action against the insurgents and find a solution without their involvement. The Awami League government, on the other hand, realized that no meaningful solution would be achieved without the involvement of insurgents, thus making a complete departure from the past. It decided to bring the insurgents under the legal and constitutional bounds. The tribal leaders, who were rigid in their demand of 
self-determination with a separate legislature in the $\mathrm{CHT}$ to protect the rights of the hill people, changed their position and agreed to the establishment of the Regional Council and the Hill District Councils with adequate powers. The local self-governments are legal entities derived either from the Constitution or an Act of Parliament. The government made it very clear from the beginning that any solution has to be within the framework of the Constitution. The government, while conceding to the demands of the tribal leaders for setting up local self-governments, insisted that the insurgents surrender their arms, which they agreed to do. The Government of Awami League tookmajor initiatives in the whole peace process, and the tribal leaders were fully involved, resulting in the Accord's materialization.

It is important to consider the contents of the Chittagong Hill Tracts Peace Accord. The most important aspect of the Accord relates to measures for creating peace and security. Decisions such as the granting of general amnesty, surrender of arms, and withdrawal of criminal cases against insurgents are very significant, as it is difficult to find general agreementon such matters. The victims of insurgent activities in the local population and also in the police and the administration always tend to be against any such measure of compromise with the insurgents. But such major decisions alone can bring about reconciliation. The Accord details the power of the Regional Council and the Hill District Councils. The Regional Council has been given vast powers to oversee all aspects of administration and development activities in the $\mathrm{CHT}$. The Hill District Councils' power to recruit local police and control all matters relating to land and land administration, including power to collect land revenue, would really make the councils effective. The Hill District Councils will be able to prevent future transfer of tribal land. In the CHT, the issue of land alienation by tribals was the root cause of unrest. The Accord proposes, through a land commission, to restore land to tribals that had been illegally captured and allotted to non-tribals. The Accord outlines the package of welfare measures for the rehabilitation of refugees as well as insurgents. Measures such as the reinstatement of jobs, preference of tribals in government jobs, and making available soft loans through banks would enable quickeconomic rehabilitation. The power of the Hill District Councils on matters such as youth welfare, environmental protection, and the development of local tourism, development trade, industry and commerce, and infrastructure would encourage local initiative and lead to integrated development of the region.

Though the Accord and subsequent legislations have addressed the root causes of insurgency and the refugee flow, much would depend on the actual implementation of the terms of the Accord. The rehabilitation and resettlement of refugees and insurgents would not only call for assistance to meet their immediate requirements for dwellings and other needs, but also to provide substantial assistance so that they could engage themselves in economic activities. Refugees who have spent more than a decade in camps are not in a good position to take up any economic activity of their own. Furthermore, it would not be possible for the government tocreate jobs to employ all of them. The Bangladesh Government has projected that it needs $\$ 100$ million from external sources to develop infrastructure in the CHT. It is important that such external assistance is mobilized so that the assistance package could be made available to the refugees without much delay.Otherwise it would lead to resentment amongst the tribals and resurrect the insurgency.

In the $\mathrm{CHT}$, the role of the district administration under the charge of a Deputy Commissioner will undergo a complete change. Many aspects of administration looked after earlier by the Deputy Commissioner will now be managed by the District Councils duly supervised by the Regional Council. The non-tribals in the CHT are opposed to the vast powers which have been given to these institutions. Thus, much would depend on how objectively these institutions function. Any discriminatory action which would affect non-tribals would diturb the peace in the CHT. The work of the land commissionproposed to be set up to resolve land disputes and restore land to tribalswould perhaps be most difficult. The non-tribals who, after payment of a considerable amount, have taken possession of such land and have settled there for more than twenty years. Being dispossessed of such land now could cause major resentment. However, the land commission can easily restore to tribals these lands that have illegally possessed by non-tribals. Even in such cases, non-tribals should be paid adequate compensation. Under normal circumstances, such compensation is not payable when the land transfer is illegal, but in the CHT, the whole peace initiative is based on the philosophy of reconciliation and coexistent. Therefore, payment of such compensation will take care of resentments which will otherwise resurface. It would not be possible for the government to ensure a sufficient area of land for each tribal family to make the family economically viable. Therefore, greater emphasis should be placed on encouraging economic rehabilitation through joint activities and development of small and cottage industries. The demographic changes, which have already come about over a period, should not be disturbed. Instead, effective measures should betaken to discourage new nontribal settlers to settle in the $\mathrm{CHT}$.

Peace has returned to the $\mathrm{CHT}$ after more than a decade ofrconflict. People have heaved a sigh of relief. There has notbeen any major incident of violence in the $\mathrm{CHT}$ since the signing of the Accord. However, there are serious apprehensions in the minds of non-tribals in the $\mathrm{CHT}$ that they could be victimized. Thus, any minor law and order problem can become a major issue, which will be politicized immediately by being said that it is all because of the Accord. The continuance of the Awami LeagueGovernment is of vital importance to the Accord's successful implementation. Any change in the government at this stage would lead to mistrust, which may upset the fragile peace in the $\mathrm{CHT}$. 